\title{
Dementia: Unwelcome change has arrived and we are not ready!
}

\author{
Michael Ashby
}

Published online: 24 June 2019

(C) Journal of Bioethical Inquiry Pty Ltd. 2019

Dementia has crept up on us, rather like D.W. Winnicott's idea of the unwelcome change that we dread in the future, not realizing that it has already happened. Our own ageing is something we only see when it has arrived, through a veil of denial, as the artist Lucien Freud found when he said that he looked in the mirror every morning, misinterpreted the information that he received, and that is where his troubles started. As we age our body demands our attention, as the ego, will and life forces on one hand, and our physical capacity on the other, are increasingly mismatched. The darker side of cognitive decline has moved from being the butt of jokes around a bit of "senile" memory loss, to being one of the major challenges of the new century: a downside of (mostly) welcomed greater collective longevity than ever before in human history, bringing with it, the sting in the tail, the "epidemic" of dementia. According to the World Health Organisation, more than 50 million people now live with dementia worldwide - nearly $60 \%$ of whom live in low and middle income

\footnotetext{
M. Ashby $(\bowtie)$

Cancer, Chronic Disease and Sub-Acute Stream, Royal Hobart Hospital, Tasmanian Health Service, Medical Ethics and Death Studies, School of Medicine, College of Health and Medicine, University of Tasmania, Repatriation Centre, 90 Davey Street, Hobart, TAS 7000, Australia e-mail: michael.ashby@ths.tas.gov.au
}

countries - and every year there are nearly ten million new cases ${ }^{1}$. Coming from nowhere in the charts of death causation, dementia is now either the leading contributory cause of death, or close to it. Far more than memory loss, it is actually a remorseless process of global physical and mental decline that can cause death in its own right.. Deaths due to dementia worldwide more than doubled between 2000 and 2016, making it the fifth leading cause of all global deaths in 2016 (compared to 14th in 2000) (World Health Organisation 2018). In some higher income countries it has become a leading cause of death. In Australia, for example, deaths from the leading cause, heart disease, have decreased over the past decade, while numbers of deaths from dementia, now the second leading cause of death, have increased by $68 \%$ (Australian Bureau of Statistics 2018). It is the leading cause of death for Australian women. Being played out over years, and often unrecognized for several in the early stages, dementia is making enormous demands on patients, families, carers, health systems, and entire societies (for good information, for example in the Australian context, see https://www.utas.edu.au/wicking). The ceiling of future care demand is not known, but the 'area

\footnotetext{
${ }^{1}$ The World Health Organisation has a range of information and resources on dementia, see https://www.who.int/mental_ health/neurology/dementia/en/
} 
under the curve' of encounters with health services, resulting from dementia, is exploding all over the world. The needs for health and social care are already exceeding capacity everywhere.

The medical response is to seek ways of mitigating its effects by pharmacotherapy, bolstering sagging neurotransmitter production on the one hand, and behavior modification and environmental shaping on the other. The focus on Alzheimer's disease as a pathological entity often obscures the contribution of microvascular causes where the general message is pretty well the same for all common diseases of this time: eat sensibly, lose weight, don't smoke, drink in moderation, maintain a blood pressure of 120/80 or less, and exercise, exercise, exercise. Brain exercises are popular but probably useless unless all these other things are done.

Dementia throws up the question of biological versus biographical life. When does your biographical life end? Is life after severe cognitive failure and executive function loss really worth living? In the vernacular most people express dread and misunderstanding about this kind of existence: being a "vegetable" (although this pejorative word probably refers to a "persistent vegetative state" or PVS, as post coma unresponsive state used to be known). The changes in, and loss of, personality are a dismal prospect, probably more so for partners and other family, where it is often said that the "X" they knew died years before the physical death. For romantic partners, the lack of depth, affection, insight and feedback is devastating, and fuels frequent carer fatigue and eventual burnout.

So do we prize the life of the mind too much? What happens when a person becomes a "pleasantly" demented person, as opposed to an aggressive one? How do we reconcile great falls, from a life of outstanding academic, literary, artistic or technical capability only to be unable to remember what you had for breakfast, or how to open the door? The book about the final years of author and philosopher Dame Iris Murdoch, as described by her husband John Bayley, brought this kind of big decline into sharp focus ${ }^{2}$. For lesser mortals, that

\footnotetext{
$\overline{2}$ John Bayley wrote three memoirs about his life with wife Dame Iris Murdoch, including in her final years living with Alzheimer's disease (published 1998-1999: Iris: A Memoir of Iris Murdoch; Elegy for Iris; and, Iris and Her Friends). The 2001 film, "Iris", was based on Bayley's writings (directed by Richard Eyre, written by Richard Eyre, John Bayley, and Charles Wood, and distributed by Miramax, see https://www.miramax.com/movie/iris/).
}

is most of us, the fall maybe smaller but the loss is still amongst our greatest dreads, and significant possibilities. The biggest fear expressed by the public in everyday conversation is the loss of cognitive capacity. One advance directive package talks of treatment abatement when people can no longer recognize those around them, cannot feed or toilet themselves (Molloy 2005) The prospect of dementia is a cause for euthanasia advocates, but by its very nature, requiring the consent of a competent person in the complex procedures laid down by law in those jurisdictions where it is permitted, virtually rule out assistance to die.

To these and other issues, our dementia symposium will apply bioethical perspectives to try and find a way through a fate that we all dread (Chapman et al. 2019a; Sabat 2019; Grigorovich et al. 2019; Chapman et al. 2019; Brennan 2019; Little and Vincent 2019; Burke 2019; Williams 2019; Chapman et al. 2019b).

If you are unable to make life decisions, and care for yourself, how is this done either with you, or for you? Courts, parliaments, and ethicists have tortured the issues of substituted judgment and best interests over the last half century, almost to death, without clear resolution. Bernadette Richards, in the regular legal Recent Developments column (Richards 2019), reports on another significant UK case about withdrawal of clinically assisted nutrition and hydration for a person in a post coma unresponsive state. The foundational case is Airedale NHS Trust $v$ Bland [1993] AC 789 (Bland), which appeared to require application to court for such treatment abatement decisions in England and Wales. This recent decision clarifies that this is not the case where all parties agree. Although strictly only relevant to that jurisdiction, these UK cases grapple with universal issues of what constitutes the best interests of a patient, and who determines these. In Bland, one of their lordships even asked (rhetorically) whether a person in a permanent coma indeed had any interests in being alive.

Malcolm Parker follows on about the issue of bioethical neutrality, and the concerns that activism needs to be differentiated from scholarship in order to preserve the authority of the discipline, and normative codes that flow from it (Parker 2019).

Rabinowich et al from Israel find a high level of treatment "aggression" in a pre-clinical medical student 
attitudes study based on case scenarios. As they progress through the course they presumably come to understand the limitations of medicine and the reality of death and dying. It is also chilling to read that withdrawal of life sustaining treatment is forbidden in Israel by law (Rabinowich et al. 2019).

Macioce discusses heath care access for ethnocultural minorities, providing more of the seemingly endless evidence for social determinants of health (Macioce 2019). Raposo criticises the apparently common argument that gene editing infringes constructs of human dignity (Raposo 2019), and Larrivee and Farisco explore the perennial subject of brain death (Larrivee and Farisco 2019), by adopting a holistic anti-Cartesian angle suggesting that a solely neurological view of apparently permanent consciousness loss is limited and needs review in the light of current research in the field of mind-body connection.

Montreuil et al consider the increasingly topical area of patient engagement in health policy and planning, albeit from the angle of clinical research design (Montreuil et al. 2019). The authors from Quebec show how important co-design is to avoiding tokenism. From an ethical point of view, they posit the notion that it is important to be clear about the purpose and concerns of engagement: is it an inherent good that arises from itself, or does it need to have clearly agreed goals from the beginning? Whether you are engaged as a consumer representative or lay person, or as a patient from a particular service, it is clear that representation is probably a wobbly concept for most as these are really more skills-based appointments. The "skill" is either being an "undifferentiated" citizen (the man on the Clapham omnibus of the English legal system), at arm's length from the organisation, without any specialist knowledge, or having had a particular illness and therefore service experience. Engagement can also be through a peak body, which is a form of lobbying, or from surveys. In most cases, though, it is personal, not completely without some duality of interest, and usually without a constituency to report back to, but at least no actual conflict of interest exists.

Finally, in Critical Perspectives, Teixeira da Silva et al take a strong line on potential conflict of interest in publishing (Teixeira da Silva et al. 2019). The problem is that we all have our networks, our sociology, connections and thereby complex webs, which these days can easily be global. The idea that we can be detached from these to a place of pure neutrality is perhaps too lofty an ideal and, ultimately, unattainable. In many cultures, where the interests of the clan or family are always paramount, and all other allegiances are considered secondary, especially trust in the state, maybe the first aim to fostering a neutral public space should be at least transparency.

\section{References}

Australian Bureau of Statistics. 2018. Australia's leading causes of death, 2017. In 3303.0 - Causes of Death, Australia, 2017. September 26. https://www.abs.gov.au/ausstats/abs@. nsf/mf/3303.0. Accessed 4 June 2019.

Brennan, F. 2019. A response to "Fragile objects: a visual essay". Journal of Bioethical Inquiry 16(2). https://doi. org/10.1007/s11673-019-09919-z

Burke, L. 2019. Dementia and the Paradigm of the Camp: Thinking Beyond Giorgio Agamben's Concept of "Bare Life". Journal of Bioethical Inquiry 16(2). https://doi. org/10.1007/s11673-019-09913-5.

Chapman, M., J. Philip, S. Gardner, P. Komesaroff. 2019. Fragile objects: A visual essay. Journal of Bioethical Inquiry 16(2). https://doi.org/10.1007/s11673-019-09911-7

Chapman, M., J. Philip, P. Komesaroff. 2019a. Towards an Ecology of Dementia: A Manifesto. Journal of Bioethical Inquiry 16(2). https://doi.org/10.1007/s11673-019-09910-8.

Chapman M., J. Philip, P. Komesaroff. 2019b. Learning From the Cultural Challenge of Dementia. Journal of Bioethical Inquiry 16(2). https://doi.org/10.1007/s11673-019-09916-2.

Grigorovich, A., Kontos, P. \& Kontos, A.P. 2019. The "Violent Resident": A Critical Exploration of the Ethics of Residentto-Resident Aggression. Journal of Bioethical Inquiry 16(2). https://doi.org/10.1007/s11673-019-09898-1

Larrivee D., M. Farisco. 2019. Realigning the Neural Paradigm for Death. Journal of Bioethical Inquiry 16(2). https://doi. org/10.1007/s11673-019-09915-3.

Little, M. \& Vincent, P. 2019. The liminal world of dementia. Journal of Bioethical Inquiry 16(2). https://doi. org/10.1007/s11673-019-09917-1

Macioce. F. 2019. The Right to Accessible and Acceptable Healthcare Services. Negotiating Rules and Solutions With Members of Ethnocultural Minorities. Journal of Bioethical Inquiry 16(2). https://doi.org/10.1007/s11673-019-09900-w.

Molloy, D.W. 2005. Let Me Decide: What You Need to Know Now about End-Of-Life Care. Canada: Penguin Books Canada.

Montreuil, M., J.T. Martineau, E. Racine. 2019. Exploring Ethical Issues Related to Patient Engagement in Healthcare: Patient, Clinician and Researcher's Perspectives. Journal of Bioethical Inquiry 16(2). https://doi.org/10.1007/s11673019-09904-6. 
Parker, M. 2019. Misconceiving "Neutrality" in Bioethics: Rejoinder to "Bioethics and the Myth of Neutrality". Journal of Bioethical Inquiry 16(2). https://doi. org/10.1007/s11673-019-09907-3.

Rabinowich, A., I. Sagy, L. Rabinowich, L. Zeller, A. Jotkowitz 2019. Withholding Treatment From the Dying Patient: The Influence of Medical School on Students' Attitudes. Journal of Bioethical Inquiry 16(2). https://doi.org/10.1007/s11673019-09897-2.

Raposo, V.L. 2019. Gene Editing, the Mystic Threat to Human Dignity. Journal of Bioethical Inquiry 16(2). https://doi. org/10.1007/s11673-019-09906-4.

Richards, B. 2019. Considering the boundaries of decision-making authority: An NHS Trust v Y [2018] UKSC 46. Journal of Bioethical Inquiry 16(2). https://doi.org/10.1007/s11673-01909914-4.

Sabat, S.R. 2019. Dementia Beyond Pathology: What People Diagnosed Can Teach Us About Our Shared Humanity. Journal of Bioethical Inquiry 16(2). https://doi.org/10.1007/s11673-019-09899-0
Teixeira da Silva, J.A., J. Dobránszki, R. Holla Bhar, C. T. Mehlman. 2019. Editors Should Declare Conflicts of Interest. Journal of Bioethical Inquiry 16(2). https://doi. org/10.1007/s11673-019-09908-2

Williams, T.C. 2019. Bioethical inquiry. https://doi.org/10.1007 /s11673-019-09920-6.

World Health Organisation. 2018. Fact sheet: The top 10 causes of death. May, 24. https://www.who.int/en/news$\mathrm{room} /$ fact-sheets/detail/the-top-10-causes-of-death. Accessed June 4, 2019.

Publisher's note Springer Nature remains neutral with regard to jurisdictional claims in published maps and institutional affiliations. 